\title{
Transcript Activities Report Management System Online
}

\author{
Luxsanan Ploywattanawong and Jeerasak Phumcharoen, Member, IACSIT
}

\begin{abstract}
This paper focus on developments that support evaluation system for the TRMS online. The objective of the study is to evaluate the user satisfaction to the TRMS. The populations for evaluated user satisfaction were undergraduate students and instructors from Faculty of Science and Technology, Rajamangala University of Technology Suvarnabhumi (RMUTSB), Suphanburi campus. The samples were sampling by Purposive Sampling method. The samples were divided into two groups, which are hundred and two students and twenty instructors. The results showed high level of user satisfaction toward TRMS. The average user satisfaction of students and instructors to the system were 4.48 and 4.59 , respectively. The highest level of satisfaction indicated that TRMS help instructors in teaching and evaluation. The data showed high level of satisfaction for both students and instructors. The TRMS has been fully developed. Moreover, this system can be used in monitoring management, evaluating, scoring process, and reporting the activities of the students, resulted in the promoting of the education management system of RMUTSB.
\end{abstract}

Index Terms-Transcript activities report management system online, transcript online, profile activity, activity management systems.

\section{INTRODUCTION}

Institution of higher education in Thailand has four main missions to achieve, which areto increase amount of graduate, to research, to serve society, and to preservethe arts and culture [1]. In order to increase amount of graduate with outstanding quality and meet the needs of employers, the students need to be equipped with knowledge, ability, intelligence, and ability to work with colleagues. Nowadays, students graduated with only certificatesor academic transcripts which is not enough to ensure their qualifications. Activities transcript is one of the importance factors for the employers consider when making an employment. As a result, this study was conducted regard to the importance of activities transcript preparation process, which is a complicated process. Therefore, we build the Online Transcript Activities Report Management System (TRMS) to follow up the record of student activities and assist in reporting the activities transcript.

\section{LITERATURE REVIEW}

To develop and evaluate the user satisfaction of Online Transcript Activities Report Management System (TRMS), several related literatures were delved, some of which are as

\footnotetext{
Manuscript received September 13, 2013; revised November 25. This work was supported in part by the Rajamangala University of Technology Suvarnabhumi.

The authors are with the Computer Science Department, Rajamangala University of Technology Suvarnabhumi, Suphunburi, Thailand (e-mail: luxsanun29@gmail.com, luxsanun_p@rmutsb.ac.th).
}

follows.

The information among huge number of documents become a problem. A recent study shows positive feedback from students towards establishing a document management system. In local universities, new innovative tools are necessary to access relevant information. In faculty of university, students are interested to have a system to manage, retrieve and sharing documents. Document management system in faculty can improve efficiency and effectiveness of research and also can improve knowledge sharing among students and get new idea from other researches. Students need a well-organized knowledge repository in order to reuse information throughout the research, in creating new opportunities for collaboration, coordination, and information exchange among students that work on a construction project [2].

The development of a user-friendly report editor that produces documents compliant to the DICOM Structured Report -DICOM SR- standard. The strategy chosen to develop the editor was to combine a documentation template editor with a report instance editor that allows the use of previously built templates to ease the process of creating reports. The developed template editor helps the user though building report structures by indicating which information items are needed in order to document a particular type of examination and suggesting values for the information items. The report instance editor represents reports in an easily understandable graphical visualization, and allows the user to create and edit structured reports permitting the use of templates as start points [3].

The tasks which the Project Managers performed when specification changes were requested by the customers have been extracted from the reports of 49 system integration projects by means of text mining technology. The results of the analysis agree with an empirical rule of Project Managers who have experience in many system development projects. The considerable efforts which the Project Managers (PM) expend in defining the specifications, accounting for additional costs in developing the system, getting a temporary purchase order from the customer, proposing a feasible delivery date to a customer and arriving at an agreement with a customer are quantified. The relationship between these efforts and the price of the system, and the number of specification changes is discussed [4].

From research of above, showing the importance and implementation of information systems to be used to collect, access and retrieve the data warehouse, the support speed of the work for educational institutions efficiently. Has been applied to the evaluation of the data and retrieved the activities of students in university.

\section{Methodology}

In this study, the populations were undergraduate students 
from Faculty of Science and Technology, Rajamangala University of Technology Suvarnabhumi (RMUTSB), Suphanburicampus. The samples were sampling by Purposive Sampling method [5].The instrument in this research consist of TRMS, and TRMS user satisfaction surveys. Then perform the research, collected the data, and analyze the results.

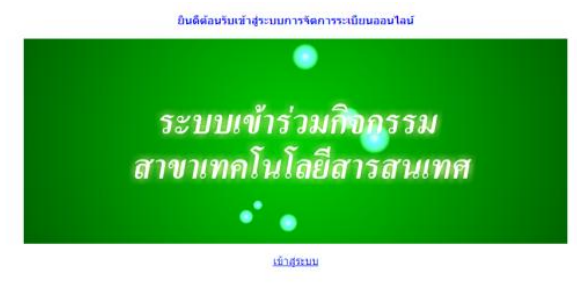

Fig. 1. Introduction pages of website.

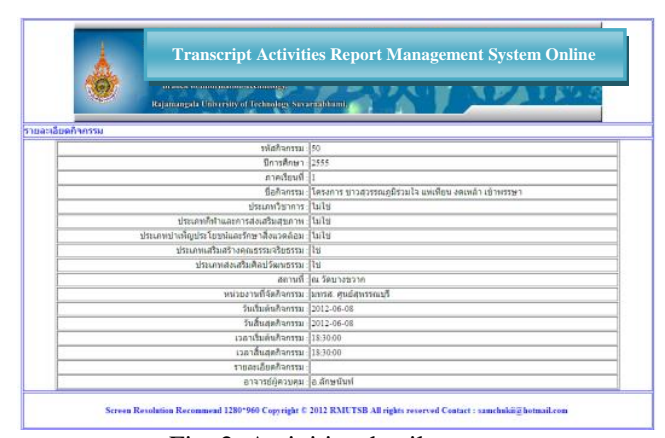

Fig. 2. Activities detail pages.

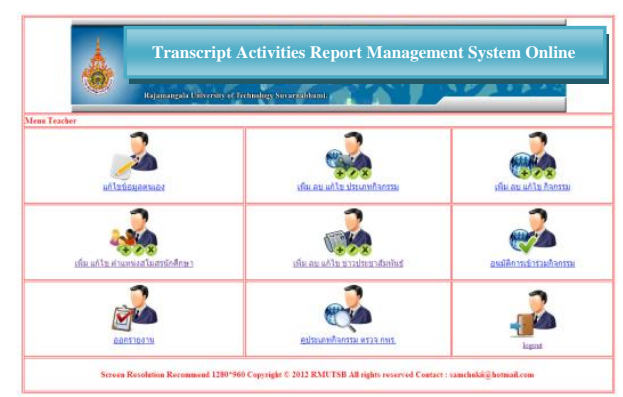

Fig. 3. Main pages of system administrator.

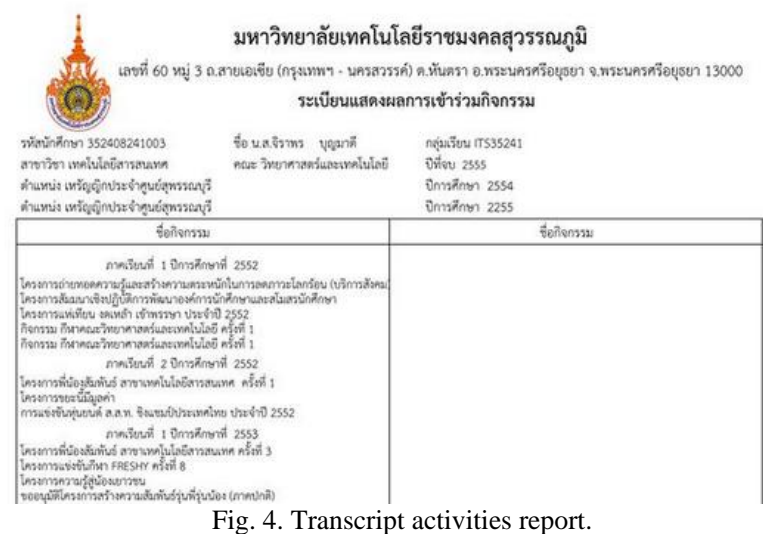

The users in a TRMS were categorized into three groups. First, advisor of activities users (instructors and system administrator), who have permission to access all functions for managing the system. This group of users were able to edit profile, add/remove/edit activities type, add/remove/edit activities detail, add/edit student positions, add/remove/edit news, approve activities participation, report the activities transcript, view the activities schedule, check the office of the
Public Sector Development Commission, and manage system logout. The second group was student users who can access the system as follows: view the news, edit profile, view activities attendance, and manage system logout. The last group was guest users. This group of user can view only the news from TRMS. The TRMS has facility to produce the Transcript Activities Report and follow up the activities attendance of each student. As shown in Fig. 1-Fig. 4.

\section{RESUlTS AND DiscUSSION}

The results of TRMS user satisfaction were collected from undergraduate students and instructors from Faculty of Science and Technology, Rajamangala University of Technology Suvarnabhumi (RMUTSB), Suphanburi campus. The results of all user satisfaction are at an excellent level.

Survey was used as a research methodology in order to evaluate the user satisfaction level. The survey form is a rating scale and the scales were classified into five levels, which are summarize the score in form of interval scale [6] as follows:

$\begin{array}{lll}\text { Excellent } & 5 & \text { points } \\ \text { Very good } & 4 & \text { points } \\ \text { Good } & 3 & \text { points } \\ \text { Fair } & 2 & \text { points } \\ \text { Poor } & 1 & \text { points }\end{array}$

Then we calculated the average of score, and compute the significant level of user satisfaction. The calculations for significant level of user satisfaction were shown as follow:

$$
\text { a) } \begin{aligned}
\text { Range } & =\text { Maximum point }- \text { Minimum point } \\
= & 5-1 \\
= & 4
\end{aligned}
$$

b) Class interval = Range /number of interval

$$
=4 / 5
$$$$
=0.8
$$

The average points as follows:

- 4.21 - 5.00: mean the users have an excellent level of satisfaction to the system.

- $3.41-4.20$ : mean the users have a very good level of satisfaction to the system.

- 2.61 - 3.40: mean the users have a good level of satisfaction to the system.

- 1.81 -2.60: mean the users have a fair level of satisfaction to the system.

- 1.00 - 1.80: mean the users have a poor level of satisfaction to the system.

Rating scale provides an effective method for measuring the user satisfaction, which are classified into five levels from highest (5) to lowest (1). For example, 5 mean that the user has highest satisfaction to the system.

The results from satisfaction survey of instructors to TRMS were summarized as follows:

Table I shown average and standard deviation (S.D.) of instructor satisfaction to TRMS. The highest average point of instructor satisfaction was 4.59. The instructors have high level of satisfaction to the system in all topics. Therefore, the instructors were very satisfy this developed system (See Table I). 
TABLE I: THE ARRANGEMENT OF CHANNELS

\begin{tabular}{|c|c|c|c|c|}
\hline & Topics & $\begin{array}{c}\text { average } \\
\text { points }\end{array}$ & "S.D. & $\begin{array}{c}\text { Satisfaction } \\
\text { Level }\end{array}$ \\
\hline 1 & $\begin{array}{l}\text { The web site has a } \\
\text { beautiful design and } \\
\text { appropriate function to } \\
\text { use. }\end{array}$ & 4.45 & 0.68 & Excellent \\
\hline 2 & $\begin{array}{l}\text { The web site is easy and } \\
\text { convenience to used }\end{array}$ & 4.65 & 0.58 & Excellent \\
\hline 3 & $\begin{array}{l}\text { The data in website are } \\
\text { reliable. }\end{array}$ & 4.60 & 0.50 & Excellent \\
\hline 4 & $\begin{array}{l}\text { The website are display } \\
\text { the information fast. }\end{array}$ & 4.55 & 0.51 & Excellent \\
\hline 5 & $\begin{array}{l}\text { The website is } \\
\text { comfortable to use. }\end{array}$ & 4.45 & 0.82 & Excellent \\
\hline 6 & $\begin{array}{l}\text { The website has high } \\
\text { performance in data } \\
\text { editing. }\end{array}$ & 4.60 & 0.59 & Excellent \\
\hline 7 & $\begin{array}{l}\text { The website provides an } \\
\text { effective solution for } \\
\text { education. }\end{array}$ & 4.45 & 0.75 & Excellent \\
\hline 8 & $\begin{array}{l}\text { The data in website is } \\
\text { useful for teaching and } \\
\text { learning of the users. }\end{array}$ & 4.75 & 0.44 & Excellent \\
\hline 9 & $\begin{array}{l}\text { The website is useful for } \\
\text { instructors and student. }\end{array}$ & 4.70 & 0.47 & Excellent \\
\hline \multirow[t]{2}{*}{10} & $\begin{array}{l}\text { The satisfaction to the } \\
\text { online evaluation system }\end{array}$ & 4.70 & 0.47 & Excellent \\
\hline & $\begin{array}{l}\text { Total Mean points } \\
\text { (10 questions) }\end{array}$ & 4.59 & 0.58 & Excellent \\
\hline
\end{tabular}

The Students satisfaction to TRMS survey results were summarized as follows:

\begin{tabular}{|c|c|c|c|c|}
\hline & Topics & $\begin{array}{c}\text { average } \\
\text { points }\end{array}$ & S.D. & $\begin{array}{l}\text { Satisfaction } \\
\text { Level }\end{array}$ \\
\hline 1 & $\begin{array}{l}\text { The web site has a } \\
\text { beautiful design and } \\
\text { appropriate function to } \\
\text { use. }\end{array}$ & 4.30 & 0.78 & Excellent \\
\hline 2 & $\begin{array}{l}\text { The web site is easy and } \\
\text { convenience to used }\end{array}$ & 4.57 & 0.69 & Excellent \\
\hline 3 & $\begin{array}{l}\text { The data in website are } \\
\text { reliable. }\end{array}$ & 4.47 & 0.67 & Excellent \\
\hline 4 & $\begin{array}{l}\text { The website are display } \\
\text { the information fast. }\end{array}$ & 4.45 & 0.62 & Excellent \\
\hline 5 & $\begin{array}{l}\text { The students can check } \\
\text { the grade results easier } \\
\text { and faster than usual } \\
\text { process. }\end{array}$ & 4.35 & 0.84 & Excellent \\
\hline 6 & $\begin{array}{l}\text { The students are } \\
\text { convenient to register } \\
\text { and follow for } \\
\text { examination request. }\end{array}$ & 4.52 & 0.65 & Excellent \\
\hline 7 & $\begin{array}{l}\text { The website promote a } \\
\text { good } \\
\text { learningandbehaviorof } \\
\text { students. }\end{array}$ & 4.34 & 0.80 & Excellent \\
\hline 8 & $\begin{array}{l}\text { The data in website is } \\
\text { useful for teaching and } \\
\text { learning of the users. }\end{array}$ & 4.63 & 0.61 & Excellent \\
\hline 9 & $\begin{array}{l}\text { The website is useful for } \\
\text { instructors and student. }\end{array}$ & 4.61 & 0.54 & Excellent \\
\hline \multirow[t]{2}{*}{10} & $\begin{array}{l}\text { The satisfaction to the } \\
\text { online evaluation system }\end{array}$ & 4.59 & 0.60 & Excellent \\
\hline & $\begin{array}{l}\text { Total Mean points } \\
\text { (10 questions) }\end{array}$ & 4.48 & 0.68 & Excellent \\
\hline
\end{tabular}

Table II shown average and standard deviation (S.D.) of students satisfaction to TRMS. From Table II, the highest average point of student satisfaction to TRMS was 4.48. The students have high level of satisfaction to the system in all topics. Therefore, the students were satisfied this developed system (See Table II).

\section{CONCLUSION}

In this research, we developed the Transcript activities report management system online (TRMS). We also evaluated the user satisfaction to the developed system. The TRMS provides facilitate and minimize the redundancy in student activities evaluation process. The system is a useful and effective tool for instructors to follow up and disseminate the student activities information. The system also offers assistance to the Student Affairs of RMUTSB with its fast and effective processing.

The average instructors and students satisfaction to TRMS were 4.59 and 4.48, respectively. Both instructors and students have very high level of satisfaction to the system. Besides that, in the same way, this system has ability to evaluate the student activities scores, reduce the mistake and complication of information, and provide an easy way to collect/check the document in systematic manner. Lastly, the students are simply able to follow their student activities and activities score.

\section{FUTURE PLANS}

It would be more benefit to add a chat system to the TRMS, which provides the opportunity for students to contact with the instructor easily. Developing more data security and facilities to the system is also an interesting area needed to be consider. Moreover, the system should not only be connected to the student record database of Faculty of Science and Technology, but it should be extended to the TRMS of other faculty in the RMUTSB for educational profit.

\section{ACKNOWLEDGMENT}

This work cannot complete without the great support from all faculty member and students from Faculty of Science and Technology, RMUTSB, Suphanburi campus for informing the survey and give a very useful suggestion for the development of the system.Lastly, we would like to express my gratitude to my parents, for their support and encouragement that provided the foundation for this work. If any mistake in this work we would like to welcome and will improve it in the future.

\section{REFERENCES}

[1] Commission on Higher Education, Guide to quality assurance in education, Higher education 2010, $3^{\text {rd }}$ ed., Bangkok, Thailand: Commission on Higher Education, 2011, pp. 8-16.

[2] H. Baban and S. Mokhtar. (2010). Online Document Management System for Academic Institutes. IEEE Xplore. [Online]. pp. 315-319. Available: http://ieeexplore.ieee.org/Xplore/home.jsp.

[3] M. K. Bortoluzzi, A. V. Wangenheimand, and K. Maximini. (2003). A Clinical report management system based upon the DICOM structured report standard. IEEE Xplore. [Online]. pp. 183-188. Available: http://ieeexplore.ieee.org/Xplore/home.jsp.

[4] T. Nakamura. (2005). Analysis of Project Management Reports of 49 System Integration Projects. IEEE Xplore. [Online]. pp. 485-486. Available: http://ieeexplore.ieee.org/Xplore/home.jsp.

[5] K. Wanichbuncha, Data Analysis for SPSS for Windows, $3^{\text {rd }}$ ed., Bangkok: Chulalongkorn University, 1999.

[6] K. Wanichbuncha, Statistic for Research, $2^{\text {nd }}$ ed, Bangkok: Chulalongkorn University, 2006. 


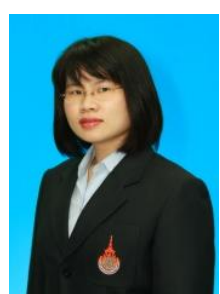

L. Ploywattanawong was born in 1980, at Sirirathospital in Bangkok, Thailand. She graduated with a master's degree in computer technology from the King Mongkut's University of Technology North Bangkok, Bangkok, Thailand in 2007. And with a Bachelor of Arts, major of Library and Information Science, Faculty of Humanities and Social Sciences, Suan Dusit Rajabhat University, Bangkok, Thailand in 2001

From 2009 to present, she is a lecturer in Department of Computer Science, Faculty of Science and Technology, Rajamangala University of Technology Suvarnabhumi, Suphanburi campus. From 2001 to 2009, Rajamagala University of Technology Rattanakosin. She is a lecturer in Department of Liberal art, Faculty of Business Administration. She is a database administrator, and Librarians in a Library Department.

Her research interests are focused on support teaching and learning, and knowledge of the site which appeared as, "Web-Based Instruction on Software Engineering," Proceeding of International conference on applied computer technology and Information Systems 2012, September 2012, p.p. 38- J. Phumcharoen and L. Ploywattanawong, "Information Technology Project Evaluation System," Proceeding of International conference on applied computer technology and Information Systems 2013,April 2013, pp. $7-10$.

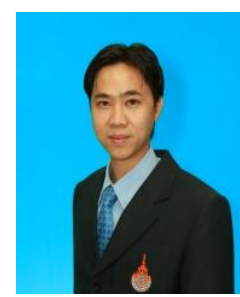

J. Phumcharoen was born in 1979, at huachiew hospital in Bangkok, Thailand. He graduated with a master's degree in 2007 and a bachelor's degree in 2001 in computer technology from the King Mongkut's University of Technology North Bangkok, Bangkok, Thailand.

Form 2001 to present he is a head of the Department of Computer Science, and meanwhile he was a lecturer, Faculty of Science and Technology Rajamangala University of Technology Suvarnabhumi, Suphanburi campus.

His research is focused on database and database management systems on site. His research topics interests are database, web-based, and oracle which appeared as, "Check Studies System on Network," Proceeding of International conference on applied computer technology and Information Systems 2012, September 2012, pp. 41-.J. Phumcharoen and L. Ploywattanawong, "Information Technology Project Evaluation System," Proceeding of International conference on applied computer technology and Information Systems 2013,April 2013, p.p. 7-10.P.Songsangyos and J. Phumcharoen, "Influencing Factors to Study in Faculty of Science and Technology," Proceeding of 2nd International conference on industrial engineering and service science, Surabaya, Indonisia, August 2013, pp J10-1-5. 